\title{
The Development of Volleyball Skill Test for Advanced Levels Student at Coaching Department of Sport Science Faculty in Padang State University
}

\author{
Zonifa Garri $^{1 *}$, Alnedral $^{1}$, Yendrizal $^{1}$ \\ ${ }^{1}$ Sport Coaching Education Program, Faculty of Sport Science, Universitas Negeri Padang, Indonesia \\ "Corresponding author. Email: garrizonifa0303@gmail.com
}

\begin{abstract}
The problem of this study was there is no valid and reliable test for measuring volleyball learning outcomes in the advanced level class at Coaching Department of Sport Science Faculty in Padang State University. This study aimed to determine the validity and reliability of the development of volleyball skill test for advanced levels student at Coaching Department of Sport Science Faculty in Padang State University. The type of this study was development test. The population in this study was the Coaching Department students who take part in the volleyball class on the advanced level from July to December 2018 which consists of 73 people, consisting of 59 men and 14 women. Samples were withdrawn by 25\% (40 males and 10 females) with Proposive Sampling. So, the samples in this study were 40 men. Data were analyzed manually with the Product Moment formula from Pearson and Werry Doolittle Method. The results of data analysis got from both validity and reliability testing related to volleyball skill test for advanced level student at Coaching Department of Sport Science Faculty in Padang State University are as follows: 1). The lower passing test obtained validity of 0.733 in the high category and reliability of 0.904 in the high category. 2) Top passing test obtained validity of 0.724 in high category and reliability of 0.905 in high category. 3) Service test obtained validity of 0.718 in the high category and reliability of 0.913 in the high category. 4) Smash tests obtained validity of 0.726 in the high category and reliability of 0.906 in the high category. 5) Block tests obtained validity of 0.790 in the high category and reliability of 0.925 in the high category. 6) Test of volleyball skills obtained validity of 0.837 and reliability of 0.973 both categories were very high.
\end{abstract}

\section{Keywords: Validity Test, Reliability Test, Advanced Volleyball Skill}

\section{INTRODUCTION}

Education is one of the national development fields which aims to educate the nation's life and also improve good human resources and to realize national development. Education is a very important and necessary thing for every human being to live his life [1].

The Faculty of Sport Sciences, Padang State University (FIK UNP) is one of the institutions tasked with processing educational staff in physical education and sports, where FIK UNP is an educational professional education institution in the field of sports. This is stated in [2] says "upholding intellectuality and prioritizing professional services in the field of sports as a service to the interests of regional and national development".

Evaluation is a systematic process for determining value decisions based on data collected through measurement.

"In terms of evaluation, it is noted that where students/athletes move according to the instructions assigned by the instructor in its implementation, students/athletes must know/know what is expected from learning, accept assignments, make decisions while explaining assignments, and accept feedback, [3]. "

Thus, before determining the value must be determined first the type of volleyball skills test the appropriate level of deepening, so that in determining the results of learning volleyball skills achieved by students in lectures is not wrong.

Skill tests are a tool used to measure skills specifically for certain sports, in this case the right tools/tests are needed. The skill test must be able to distinguish the skill level of the person trying correctly, for that the skill test must have high validity and reliability [4].

Volleyball is a continuation of the deepening level volleyball ground level, which was attended by students and graduate with a minimum grade $\mathrm{B}$. In the lecture deepening level volleyball, volleyball teaching team have to show some form of skills tests in lectures deepening levels consisting of a test service, lower passing, top passing and smash. This test aims to find out where the teaching and learning process has been achieved in 
accordance with the lecture syllabus and the existing curriculum.

\section{METHOD}

\subsection{Method and Research Design}

This study was entitled "Development of the Volleyball Skill Test for the Level of Deepening of Student Training Programs at the Faculty of Sport Sciences, Padang State University". Aiming to determine the extent of the validity and reliability of the test in accordance with the title, this type of research is classified into the type of test development research. Retrieval of data in this study was carried out on UNP FIK Coaching Department students who took volleyball courses in the level of July-December 2018 semester totaling 40 people conducted on December 22-23 2018 at 08.00 WIB until completion and carried out at the Gymnasium Volleyball Court (GOR ) FIK UNP.

\subsection{Research Instruments}

1. Tests skills already developed include service top, passing, bottom passing over, smash and block.

2. Play skill tests assessed by two Judges or more.

Instrument Validity Test is a method that shows the level of validity or validity of an instrument. Instruments are declared valid if they are able to measure what they want to measure. Validity analysis is by correlating the scores on each item with the total score, while the formula used is the formula proposed by Pearson, better known as "Correlation Formula Product Moment". Next, test the validity of the test (battery test) using the Werry Doolittle Method.

Validity Criteria, [5]

\begin{tabular}{cc}
\hline Score Interval & Category \\
\hline $0.80-1.00$ & Very High \\
$0.70-0.79$ & Height \\
$0.50-0.69$ & Enough \\
$0.00-0.49$ & Unacceptable \\
\hline
\end{tabular}

Instrument Reliability Test after the validity criteria are known, then test the reliability of the instrument using the method test-retest orby correlating the scores on each item with the total score, while the formula used is the formula proposed by Pearson, better known as the term "Correlation Formula Product Moment".

Reliability Criteria, [5]

\begin{tabular}{cc}
\hline Interval Score & Category \\
$0.93-1.00$ & Very High \\
$0.88-0.92$ & Height \\
$0.68-0.87$ & Enough \\
$0.00-0.67$ & Unacceptable \\
\hline
\end{tabular}

Before conducting a correlation analysis, a normality test is conducted first to find out whether the data comes from normal distribution or not, using the test statistic Lilliefors with a significant level of $a=0.05$. The results of the normality test for all data can be concluded to be normally distributed.

\section{a. Calculating the Validity of the Skill Test Lower Passing}

From the results of the data calculation using the correlation Product Moment from Pearson, the correlation coefficient of the skill lower passing $\left(\mathrm{r}_{\mathrm{x} 1 \mathrm{y}}\right)$ is, which is 0,733 . The results obtained are greater than $r$ contained in the table, namely $r_{\text {tabel }} 0.312$. It can be said that the correlation between the skill test lower passing and the results of the evaluation of two judges shows a positive relationship, belonging to the high category and declared valid.

\section{b. Calculating the Reliability of the Skill Test Lower Passing}

The statistical analysis used is the correlation Product Moment from Pearson. From the correlation analysis obtained a correlation coefficient of $r_{x 1 \times 1 a}=0,904$. The results obtained are greater than $r$ contained in the table, namely $\mathrm{r}_{\text {table }} 0,312$. It can be said that the correlation between lower passing the first test (test I) and lower passing the second day's test (test II) showed a positive relationship, including in the high category and stated reliably.

\section{c. Calculating the Validity of the Skills Test Top Passing}

From the results of the calculation of the data using the correlation Product Moment from Pearson, the correlation coefficient for the skill top passing $\left(\mathrm{r}_{\mathrm{x} 2 \mathrm{y}}\right)$ is obtained which is 0,724 . The results obtained are greater than $r$ contained in the table, namely $r_{\text {table }} 0,312$. It can be said that the correlation between the skill test top passing and the assessment results of two judges showed a positive relationship, belonging to the high category and declared valid.

\section{d. Calculating the Reliability of the Skill Test Top Passing}

The statistical analysis used is the correlation Product Moment from Pearson. From the correlation analysis obtained a correlation coefficient of $r_{x 2 y}=0,905$. the results obtained are greater than $\mathrm{r}$ contained in the table, namely $\mathrm{r}_{\text {table }} 0.312$. It can be said that the correlation between the skills test top passing on the first day (test I) and the skill test top passing on the second day (test II) showed a positive relationship, including in the high category and declared reliable.

\section{e. Calculating the Validity of Skills Tests Service}

From the results of the calculation of data using the correlation Product Moment from Pearson, the correlation coefficient of skill test service $\left(\mathrm{r}_{\mathrm{x} 3 \mathrm{y}}\right)$ is obtained which is 0.718 . The results obtained are greater than $r$ contained in the table, namely $\mathrm{r}_{\text {table }} 0.312$. It can be said that the correlation between the skill test service and the assessment results of two judges shows a positive relationship, belonging to the high category and declared valid. 


\section{f. Calculating Reliability of Skills Tests Service}

From the correlation analysis obtained a correlation coefficient of $r_{\times 3 \times 3 a}=0,913$. The results obtained are greater than $r$ contained in the table, namely $r_{\text {table }} 0.312$. It can be said that the correlation between skill test sevice the first day (test I) with skill test service the second day (test II) that has been examined in this study shows a positive relationship, including in the high category and declared reliable.

\section{g. Calculating the Validity of the Skill Test Smash}

From the results of calculating the data using the correlation Product Moment from Pearson, the correlation coefficient of the skill test smash $\left(\mathrm{r}_{\mathrm{x} 4 \mathrm{y}}\right)$ is obtained which is 0,726 . The results obtained are greater than $r$ contained in the table, namely $r_{\text {table }} 0,312$. It can be said that the correlation between the skill test smash and the results of the evaluation of two judges shows a positive relationship, belonging to the high category and declared valid.

\section{h. Calculating the Reliability of the Skill Test Smash}

From the correlation analysis obtained a correlation coefficient of $\mathrm{r}_{\mathrm{x} 4 \times 4 \mathrm{a}}=0,906$. The results obtained are greater than $r$ contained in the table, namely $r_{\text {table }} 0,312$. It can be said that the correlation between skill test smash the first day (test I) and skill smash the second day test (test II) shows a positive relationship, including in the high category and declared reliable.

\section{i. Calculating the Validity of Skill Tests Block}

From the results of calculating the data using the correlation Product Moment from Pearson, the correlation coefficient skill test block $\left(\mathrm{r}_{\mathrm{x} 5 \mathrm{y}}\right)$ is obtained which is 0,790 . The results obtained are greater than $\mathrm{r}$ contained in the table, namely $\mathrm{r}_{\text {table }} 0,312$. It can be said that the correlation between the skills test block and the results of the evaluation of two judges examined in this study shows a positive relationship, belonging to the high category and declared valid.

\section{j. Calculating Reliability of Skill Tests Block}

From correlation analysis obtained a correlation coefficient of $r_{x 5 \times 5 a}=0,925$. the results obtained are greater than $r$ contained in the table, namely $r_{\text {table }} 0,312$. It can be said that the correlation between of skills tests block the first (tests I) toof skills testing block the second day (test II) has been investigated in this study shows a positive relationship, including in the high category and otherwise reliable.

\section{k. Calculating the Validity of the Development of the Volleyball Skill Test}

From the data analysis, it turns out that there is a meaningful relationship between the related variables. Because the correlation number shows $r=0,837$, it can be said that the volleyball skill test in the lecture level is valid. The validity of developing the volleyball skill test is included in the very high category.

\section{Calculating the Reliability of Developing Volleyball Skill Tests}

Based on the results of $r$ obtained at 0,973 , it can be stated that the Development of Volleyball Skill Tests in lectures in the deepening level is reliable. Reliability Development of the Volleyball Skill Test is included in the very high category.

\section{CONCLUSIONS}

The conclusion of this research are: 1) The level of validity The Development Lower Passing Test of the Volleyball in The level of depth is included in the high category $(r=0,733)$ and the reliability level is in the high category $(r=0,904)$. 2) The level of validity The Development Top Passing Test of the Volleyball in The Deepening Level was included in the high category ( $\mathrm{r}=$ $0,724)$ and the Reliability level was included in the high category $(r=0,905) .3)$ The level of validity of the Test Development of the volleyball Service in the Deepening Level is included in the high category $(r=0,718)$ and the Reliability level is included in the high category $(\mathrm{r}=$ 0,913). 4) The level of validity of the Development of the Volleyball Test Smash in The Deepening Level was included in the high category $(r=0,726)$ and the Reliability level was included in the high category $(\mathrm{r}=$ 0,906). 5) The level of validity of the Development Block of the Volleyball in The Level is included in the high category $(r=0,790)$ and the Reliability level is included in the high category $(r=0,925)$. And 6$)$ the level of validity of the Development of the Volleyball Skill Test in the Deepening Level was included in the very high category ( $\mathrm{r}$ $=0,837)$ and the Reliability level was included in the very high category $(r=0,973)$.

\section{IMPLICATIONS}

First. The implication is that physical education teachers must know the steps in making a sports skills test, a test tool needs to be considered if the test is not in accordance with the guidelines for making tests, meaning that a test is made must be guided by the steps in preparing the skill test correctly. So the test actually measures what should be measured.

Second. The implication is for teachers who will make a skill test, that the reliability of the test relates to the level of trust. A test can be said to have a high level of trust if the test gives a fixed result, then the reliability of the test is related to the problem of the determination of the test results. To be able to obtain a reliable or steady picture is indeed difficult because the psychological elements of human beings themselves are not reliable (reliable).

Other implications. The implication for teachers of Physical Education and Sports, that in making a measuring instrument consisting of several tests, it is necessary to know the validity and reliability of the test items. So that we can find out which test items are used and which will be discarded to measure students' skills. 


\section{REFERENCES}

[1] Yusmar, Ali. "Upaya Peningkatan Teknik Permainan Bolavoli Melalui Modifikasi Permainan Siswa Kelas X SMA Negeri 2 Kampar". Jurnal Pendidikan dan Pengajaran Program Studi Pendidikan Guru Sekolah Dasar FKIP Unversitas Riau. Vol 1. No 1 Juli. Pp 143152. March. 2017.

[2] FIK UNP. Buku Pedoman Akademik Universitas Negeri Padang. Padang: Press UNP. 2014.pp 4456

[3] Alnedral. Strategi Spektrum Gaya Pengajaran Pendidikan Jasmani, Olahraga dan Kesehatan. Padang: UNP Press. 2008.pp 21-45

[4] Arsil. Evaluasi Pendidikan Jasmani dan Olahraga. Padang: Wineka Media. 2009.pp 66-76

[5] Winarno. Evaluasi dalam Pendidikan Jasmani dan Olahraga. Jakarta: Center for Human Capacity Development. 2014.pp 10-53. 